\begin{tabular}{|c|c|c|}
\hline Iso 150 & $\begin{array}{c}\text { Bulletin of Pharmaceutical Sciences } \\
\text { Assiut University }\end{array}$ & 2 \\
\hline 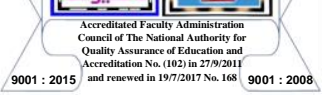 & $\begin{array}{c}\text { Website: http://bpsa.journals.ekb.eg/ } \\
\text { e-mail: bullpharm@aun.edu.eg }\end{array}$ & $\begin{array}{l}\text { BULL. PHARM. SCI. } \\
\text { Assiut Univ. }\end{array}$ \\
\hline
\end{tabular}

\title{
EVALUATION OF IN VIVO ANTIPYRETIC, HEPATOPROTECTIVE AND MOLECULAR DOCKING STUDIES OF Rhynchosia cana (Wild.)DC
}

\author{
Praveena Yempada*, Arya Lakshmi Marrisetti and Ganga Rao Battu \\ Pharmacognosy and Phytochemistry Research Division, University College of Pharmaceutical \\ Sciences, Andhra University, Visakhapatnam, Andhra Pradesh, India
}

\begin{abstract}
To assess the antipyretic and hepatoprotective effects of Rhynchosia cana (Wild.) DC (R. cana) methanol extract in In-silico trials and laboratory animal models. $R$. cana methanol extract (MERC) was evaluated for antipyretic activity in yeast-induced Pyrexia. $R$. cana's hepatoprotective ability was evaluated for hepatotoxicity-induced paracetamol albino rats. The GC-MS eluted compound on the protein TGF- $\beta$, and PPAR $\alpha$ was conducted in silico docking experiments. At doses of 200 and $400 \mathrm{mg} / \mathrm{kg}$, p.o, a single administration of MERC demonstrated strong antipyretic efficacy in albino rats. When the MERC (400 $\mathrm{mg} / \mathrm{kg}$ ) was given preventively for seven days, highly significant hepatoprotective behaviour was also observed. The docking findings of the TGF- $\beta$ ligand molecule show that the binding affinity of vitexin is $10.3 \mathrm{Kcal} / \mathrm{mol}$, and Silymarin is $-10.6 \mathrm{Kcal} / \mathrm{mol}$. Vitexin displayed a binding affinity of -8.8 $\mathrm{Kcal} / \mathrm{mol}$ for the PPAR alpha protein, and Silymarin showed an affinity of $-8.2 \mathrm{kcal} / \mathrm{mol}$. The present research indicates that MERC has substantial antipyretic and hepatoprotective effects, as confirmed in the In Silico and In Vivo tests.
\end{abstract}

\section{INTRODUCTION}

Plants represent a large pool of phytochemicals, some of which can treat different disorders as natural medicinal agents. Secondary plant metabolites are bioactive phytoconstituents and show different pharmacological responses ${ }^{1}$. Plants are used in traditional medicine schemes for several causes, including hepatoprotective and antipyretic activities ${ }^{2-5}$.

Pyrexia is a specific clinical manifestation characterized by an elevation in body temperature above the normal range. The body provides a favourable atmosphere for natural protection mechanisms through this mechanism to promote damaged tissue repair or make infectious agents unviable. Different inflammatory mediators, i.e., cytokines, are released by damaged or injured tissues, increasing $\mathrm{PGE}_{2}$ synthesis in the hypothalamus, which causes body temperature to rise ${ }^{6}$. Nearly all new antipyretic medications obstruct $\mathrm{PGE}_{2}$ synthesis through inhibition of the COX-2 enzyme. Most of these chemotherapeutic drugs bind with the COX-2 enzyme irreversibly. These synthetic agents are harmful to the brain, heart, liver, and kidneys. In comparison, standard COX-2 antagonists have been found to have significantly less harmful effects ${ }^{7 \& 8}$.

Worldwide, liver disorders account for nearly millions of death each year'. Despite drug-induced hepato-injury is uncommon, it remains a substantial clinical issue due to its unexpected nature and possibly lethal route. In adolescents, drug-induced hepatic disease accounts for up to 20 per cent of acute liver failure. It is impossible to track the actual occurrence, although approximately 40,000 to 45,000 persons per year may suffer a druginduced liver injury ${ }^{10}$. Paracetamol is one scientifically appropriate medication that has been correlated with liver damage. It is the most widely used analgesic and antipyretic drug; despite being the most frequent source of acute liver failure in Western cultures, it may be obtained without medication in most nations ${ }^{11}$. An excess of Paracetamol in humans

Received in 25/5/2021 \& Accepted in 20/6/2021 
and animals can cause severe liver injury, liver necrosis ${ }^{12}$, and kidney damage ${ }^{13}$. Necessary attempts have been made to clarify the causes of its toxic impact, considering the public interest generated by Paracetamol (PCM) hepatotoxicity. Several reports suggest that oxidative stress is implicated in multiple toxicities associated with PCM, including PCM-induced liver disease.

In the twenty-first century, a paradigm change in the application of medicinal ingredients for therapeutic purposes in liver disease models was demonstrated by deliberately integrating the capabilities of traditional medicine with the new definition of evidence-based therapeutic screening, authentication, and placebo-managed randomized controlled trials to enhance clinical efficacy. No significant and stable hepatoprotective medication is available, considering the enormous advances achieved. The manufacture of hepatoprotective medicines, primarily plant-based, effective against various liver disorders, has been given high global consideration.

Rhynchosia cana, a Leguminosae member, is an example of a herb used in herbal medicine to cure deadly illnesses. There are approximately 300 Rhynchosia species distributed all over the world. It is a shrub; branchlets glandular, pubescent. Terminal leaflets to $5 \times 2.5 \mathrm{~cm}$, laterals $3 \times 1.5 \mathrm{~cm}$, ovate, acute, inequilateral, pubescent; stipule $2 \mathrm{~mm}$, lanceolate. Flowers axillary, in pairs, yellow; pedicels $5 \mathrm{~mm}$, deflexed; bracts $1.5 \mathrm{~mm}$; calyx tube $2 \mathrm{~mm}$, lobes 3 and $1 \mathrm{~mm}$, lanceolate, pubescent; corolla $8 \mathrm{~mm}$ long; staminal tube 5 $\mathrm{mm}$; anthers uniform; ovary pubescent, stigma capitate. Pod $1.5 \times 0.7 \mathrm{~cm}$, oblong, puberulous to glabrous; seeds 1 or 2 . This plant finds use in conventional medicine viz., the bark decoction for dysentery ${ }^{14}$-leaves used for wounds, cuts, boils, and rheumatic pains. The phytochemicals of $R$. cana explored were vitexin, Vicenin-2, Orientin, Isoorientin ${ }^{15}$. The flowers of $R$. cana demonstrate anti-inflammatory and antipyretic activity ${ }^{16}$. Recent studies also confirmed the genus' pharmacological and biological activities, such as anti-oxidant, antimicrobial, antimicrobial, anti-inflammatory, antiangiogenic, and antityrosinase antiproliferative and allelopathic activities ${ }^{17}$.
Thus, to rationalize MERC's indigenous usage as a febrifuge, we attempted to test its antipyretic efficacy and the influence of MERC on hepatoprotective activity using a paracetamol-induced hepatotoxicity model and In-silico study.

\section{METHODS AND MATERIALS}

\section{Collection of Plant Material}

Rhynchosia cana whole plant was collected from Tirumala hills, district Chittoor, Andhra Pradesh, India, in November 2016. It was authenticated by Dr. K. Madhava Chetty, Department of Botany, Sri Venkateswara University, Tirupati, and the specimen was deposited with a voucher specimen sample No. 0887. The portions of the plant gathered were washed with water and dried at room temperature in the shade. The dried parts were ground to a coarse powder for the analysis, the powdered material was held in an airtight and light-resistant jar.

\section{Preparation of Samples}

The entire plant that was gathered was cleaned, chopped into small pieces, dried in the shade, and eventually ground into a coarse powder. In a clear, flat-bottomed glass, powdered plant material (about $400 \mathrm{~g}$ ) was taken and immersed in $2000 \mathrm{ml}$ of methanol; along with constant shaking, the glass jar with the contents was kept for 14 days.

\section{Preliminary phytochemical analysis}

The powdered plant was processed by maceration using methanol. The extract was qualitatively tested using different chemical methods for different classes of phytoconstituents ${ }^{18-20}$.

\section{GC-MS Analysis of Methanol extract of Rhynchosia cana}

Using Agilent Technology GC systems with the GC-7890A/MS-5975C model, the GCMS study of bioactive compounds of methanolic extracts of $R$. cana was carried out. Experimental conditions of the GC-MS system were as follows: TR 5-MS capillary standard non-polar column, dimension: $30 \mathrm{Mts}$, ID: 0.25 $\mathrm{mm}$, Film thickness: $0.25 \mu \mathrm{m}$. The flow rate of the mobile phase (carrier gas: $\mathrm{He}$ ) was set at 1.0 $\mathrm{ml} / \mathrm{min}$. In the gas chromatography part, the 
temperature program (oven temperature) was $40^{\circ} \mathrm{C}$ raised to $250^{\circ} \mathrm{C}$ at $5^{\circ} \mathrm{C} / \mathrm{min}$, and the injection volume was $1 \mu$ l. The proportional quantities of chemical compounds in the $R$. cana methanolic extract were expressed as a percentage based on the peak area of the chromatogram made. In the Library of NIST, a database was screened to measure significant peaks in mass spectrometry.

\section{Experimental Animals}

Wistar albino rats (160-190 g) were purchased from Mahaveer Enterprises, Hyderabad, Telangana, and acclimatized in the animal house of A U College of Pharmaceutical Sciences (AUCoPS), Visakhapatnam, for seven days under standard husbandry conditions, i.e., room temperature $(26 \pm 10){ }^{\circ} \mathrm{C}$, relative humidity $(45 \%-55 \%)$ and light and dark period $12 \mathrm{hrs}: 12 \mathrm{hrs}$.

All the experimental procedures were authorized by the IAEC of AUCoPS and executed according to the CPCSEA guidelines.

\section{Acute toxicity Studies}

In compliance with the OECD standards for testing chemicals, Test No 423, an acute oral toxicity analysis, was conducted. During the first $30 \mathrm{~min}$. after dosing, the individual animals were closely monitored regularly for the first $24 \mathrm{hrs}$ and 3 days afterward to record any delayed toxicity. When administered in doses up to $2000 \mathrm{mg} / \mathrm{kg}$ p.o., the MERC was devoid of any toxicity in rats. Therefore, doses of extracts were chosen for further analysis (200-400) $\mathrm{mg} / \mathrm{kg}^{21}$.

\section{Antipyretic Activity}

The animals were divided into six groups $(n=6)$. Fever was induced by administration of $15 \%$ w/v Brewer's yeast suspension subcutaneously ${ }^{22 \& 23}$. The rectal temperature was recorded using thermometer immediately before and $18 \mathrm{~h}$ after Brewer's yeast injection ${ }^{24}$. After $18 \mathrm{hrs}$. of yeast injection different groups received vehicle $(1 \% \mathrm{v} / \mathrm{v}$ Tween 80 in distilled water), methanol extracts (200 and $400 \mathrm{mg} / \mathrm{kg}$ body weight) and reference drug (paracetamol, $150 \mathrm{mg} / \mathrm{kg}$ body weight) through oral route.
The rectal temperature was then periodically recorded for an observation period of $4 \mathrm{hrs}$.

Hepatoprotective Activity

The In vivo hepatoprotective activity of MERC was determined using the PCM-induced hepatotoxicity test in rats. The animals were divided into 5 groups $(n=5)$ and administered with test solutions as described below.

i. Group I served as normal control and received distilled water

ii. Group II served as negative control and received distilled water.

iii. Group III served as positive control and received $50 \mathrm{mg} / \mathrm{kg}$ silymarin.

iv. Pretreatment groups

a. Group IV received $200 \mathrm{mg} / \mathrm{kg}$ MERC,

The animals were fasted for 48 hrs. prior to the experiment under standard laboratory conditions. After $48 \mathrm{hrs}$, each group of rats received the respective dose of test solution orally once daily for 7 consecutive days. The oral administration of PCM was performed 3 hrs after the last extract administration on the 7th day except for group I, which received only distilled water. Forty eight hrs after the hepatic injury induction, the animals were anesthetized using diethyl ether, and the blood was drained for biochemical parameters study. The animals were then sacrificed by cervical dislocation, and the liver was removed for histopathological studies $^{25-27}$.

\section{Analyzing biochemical serum parameters}

Using the standard AMP diagnostic kits, the activities of serum SGPT, SGOT, ALP, and total bilirubin were calculated ${ }^{28}$.

Evaluation of lipid peroxidation (LPO) and superoxide dismutase (SOD)

The excised livers were infused with chilled normal saline. They were then chopped into smaller fragments and homogenized by inserting them in a $0.1 \mathrm{M}$ phosphate buffer $(\mathrm{pH}$ 7.4). In an Eppendorf tube, the homogenate was centrifuged for 30 minutes, and the supernatant was extracted. The supernatant was used as a LOP marker to assess MDA, while SOD was also assessed ${ }^{29 \& 30}$. 


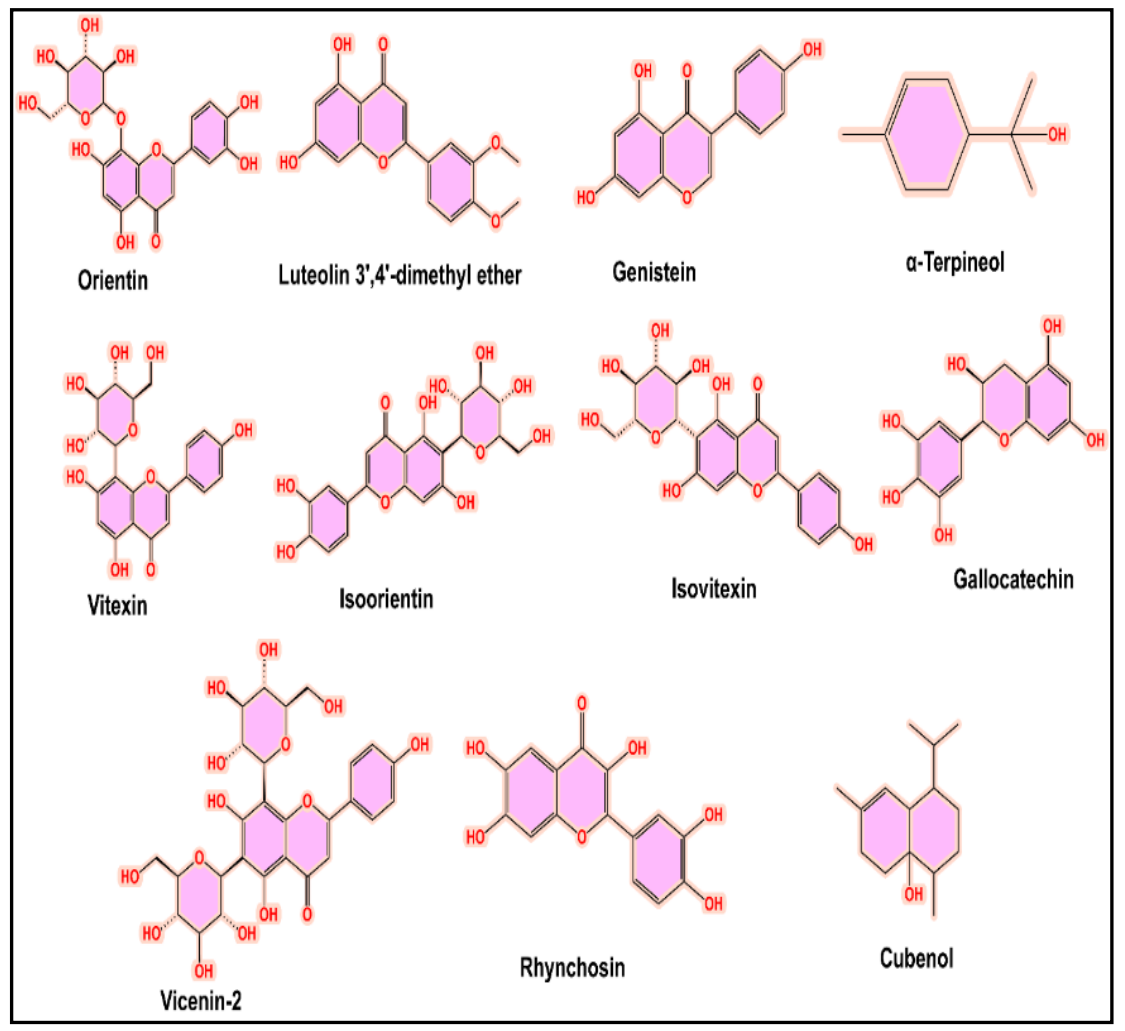

Fig. 1: 2D representation of various ligands from Rhynchosia cana

\section{Drug-likeliness}

The phytochemical constituents were retrieved from PubChem, and the compounds were transferred to SDF files and evaluated drug likeliness using DruLiTo tools ${ }^{31 \& 32}$.

\section{In-Silico Docking Studies}

To determine the relationship between the ligands (Fig. 1) and the target protein, docking

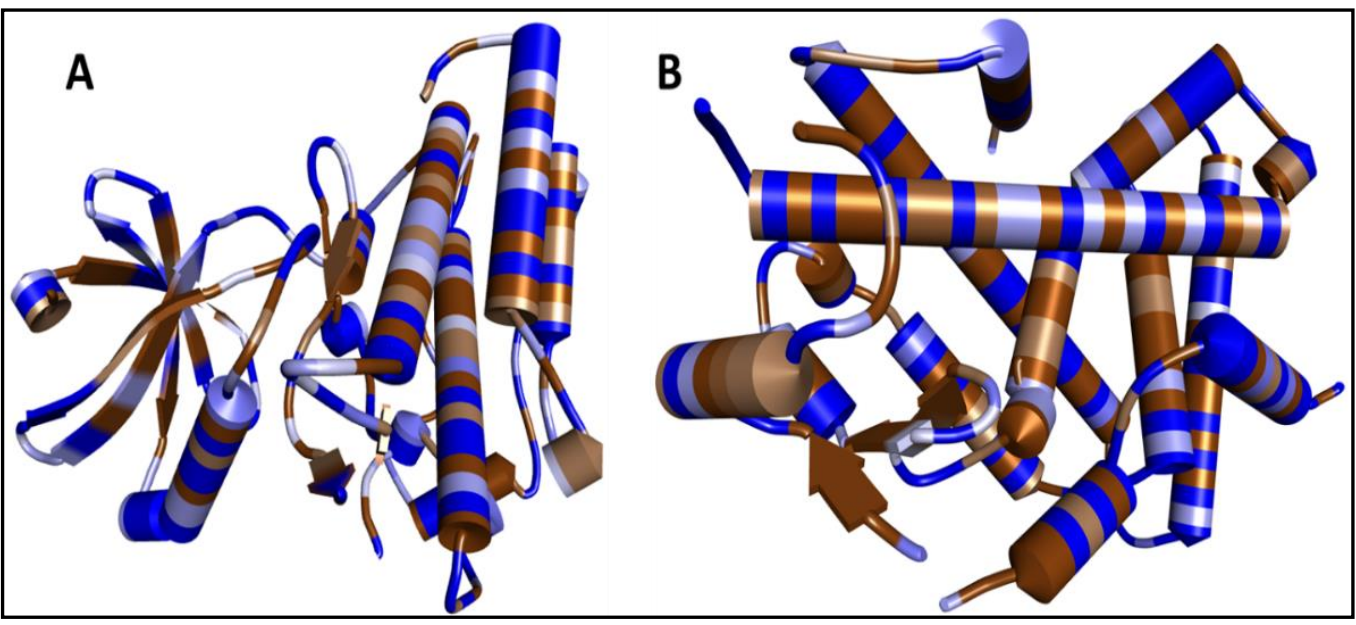

Fig. 2: 3D Presentation of targeted proteins (A) transforming growth factor- $\beta$ (PDB: IVJY) (B) peroxisome proliferator-activated receptor $\alpha$ (PPAR $\alpha$ ) (PDB ID: 5HYK) 
ADMET Analysis

Ligands' ADMET is their pharmacokinetics that needs to be studied to assess their role within the body. The ADMET inheritance of the ligands was examined using admetSAR ${ }^{35 \& 36}$.

\section{RESULTS AND DISCUSSION}

\section{Results}

Phytochemical Screening

The yield of methanol extract of $H$. aspera was found to be $8.15 \% \mathrm{w} / \mathrm{w}$. Preliminary phytochemical screening of MERC extract revealed the presence of steroids, volatile oil, saponins, fats and oils, proteins, carbohydrates, and acidic compounds

\section{GC-MS Analysis}

Eleven peaks were shown in the GC-MS chromatogram analysis of the methanolic extract of $R$. cana (Fig. 3), indicating the presence of 11 phytochemical constituents. Twelve phytocompounds were characterized and defined about the components' mass spectra and the NIST library (Table 1).

\section{Acute toxicity Studies}

No mortality up to the dosage amount of $2000 \mathrm{mg} / \mathrm{kg}$ was induced by the methanol extract of $R$. cana (MERC). Therefore, for further experiments, 200 and $400 \mathrm{mg} / \mathrm{kg}$ doses have been chosen.

\section{Antipyretic test}

Statistical analyses showed that the MERC exhibited substantial antipyretic behaviour. At 2, 3, and 4 hrs, MERC reported significant implications utilizing $400 \mathrm{mg} / \mathrm{kg}$ dosage. The inhibition was based upon the dosage. Table 2 and Fig. 4 presents the influence of the extract on the rectal temperature in rats.

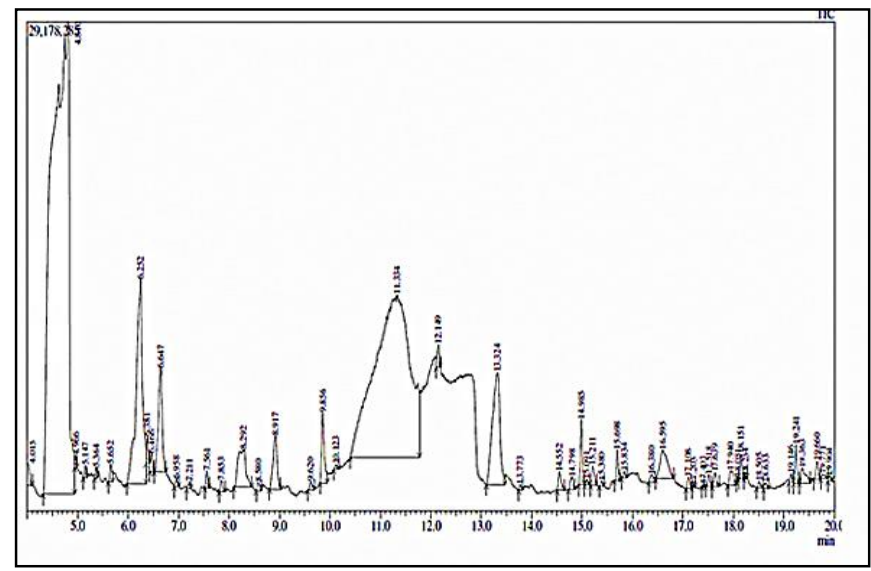

Fig. 3: GC-MS Spectral analysis of Methanol Extract of Rhynchosia cana (MERC)

Table 1: Biological active compounds identified from methanol extract of $R$. cana by GC-MS.

\begin{tabular}{|c|c|c|c|c|c|}
\hline \hline S. No Retention Time & Compound name & Area (\%) & Molecular formula & Molecular weight \\
\hline 1. & 6.252 & Orientin & 8.68 & $\mathrm{C}_{21} \mathrm{H}_{20} \mathrm{O}_{11}$ & 448.4 \\
\hline 2. & 6.647 & Luteolin 3',4'-dimethyl ether & 1.89 & $\mathrm{C}_{23} \mathrm{H}_{22} \mathrm{O}_{12}$ & 490.4 \\
\hline 3. & 8.292 & Genistein & 10.98 & $\mathrm{C}_{15} \mathrm{H}_{10} \mathrm{O}_{5}$ & 270.24 \\
\hline 4. & 8.917 & alpha-Terpineol & 5.53 & $\mathrm{C}_{10} \mathrm{H}_{18} \mathrm{O}$ & 154.25 \\
\hline 5. & 11.334 & Vitexin & 48.23 & $\mathrm{C}_{21} \mathrm{H}_{20} \mathrm{O}_{10}$ & 432.4 \\
\hline 6. & 12.149 & Isoorientin & 2.85 & $\mathrm{C}_{21} \mathrm{H}_{20} \mathrm{O}_{11}$ & 448.4 \\
\hline 7. & 13.324 & Rhynchosin & 10.14 & $\mathrm{C}_{15} \mathrm{H}_{10} \mathrm{O}_{7}$ & 302.23 \\
\hline 8. & 15.698 & Isovitexin & 2.37 & $\mathrm{C}_{21} \mathrm{H}_{20} \mathrm{O}_{10}$ & 432.4 \\
\hline 9. & 16.595 & Cubenol & 10.32 & $\mathrm{C}_{15} \mathrm{H}_{26} \mathrm{O}$ & 222.37 \\
\hline 10. & 17.940 & Vicenin-2 & 6.02 & $\mathrm{C}_{27} \mathrm{H}_{30} \mathrm{O}_{15}$ & 594.5 \\
\hline 11. & 19.241 & Gallocatechin & 2.32 & $\mathrm{C}_{15} \mathrm{H}_{14} \mathrm{O}_{7}$ & 306.27 \\
\hline
\end{tabular}




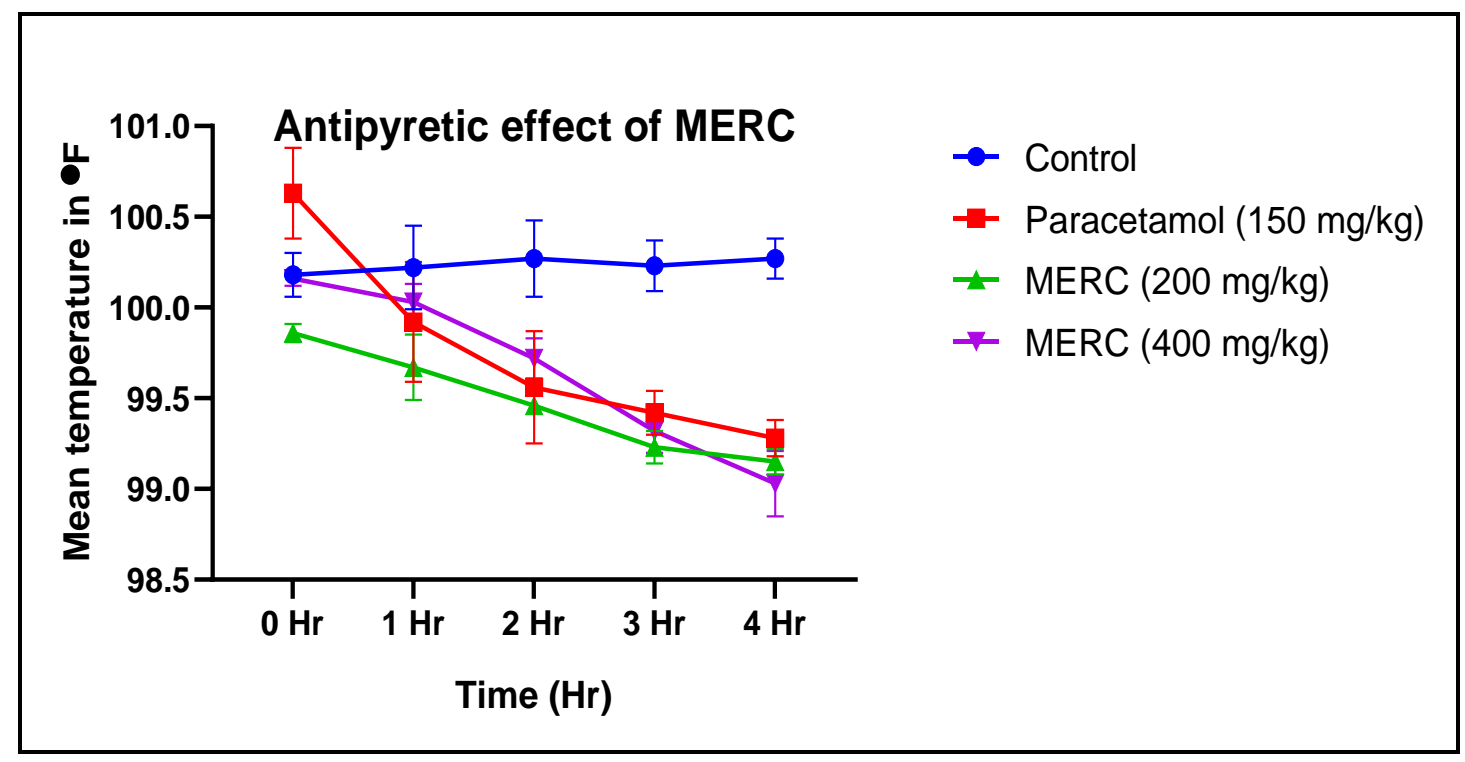

Fig. 4: Antipyretic effect of methanol extract of R. cana on albino rats

Table 2: Antipyretic activity of methanol extract of Rhynchosia cana by Brewer's yeast-induced pyrexia method

\begin{tabular}{|c|c|c|c|c|c|c|}
\hline \multirow[t]{2}{*}{ Group } & \multirow{2}{*}{$\begin{array}{l}\text { Initial rectal } \\
\text { temperature } \\
\text { before yeast } \\
\text { injection }\left({ }^{\circ} \mathrm{F}\right)\end{array}$} & \multicolumn{5}{|c|}{$\begin{array}{l}\text { The rectal temperature at yeast injection and after the } \\
\text { administration of sample }\left({ }^{\circ} \mathbf{F}\right)\end{array}$} \\
\hline & & $\mathbf{O H r}$ & 1st Hr & 2nd $\mathrm{Hr}$ & 3rd Hr & 4th $\mathrm{Hr}$ \\
\hline $\begin{array}{c}\text { Control } \\
\text { (Distilled water) }\end{array}$ & $99.22 \pm 0.15$ & $100.18 \pm 0.12$ & $100.22 \pm 0.23$ & $100.27 \pm 0.21$ & $100.23 \pm 0.14$ & $100.27 \pm 0.11$ \\
\hline $\begin{array}{c}\text { Standard } \\
\text { (Paracetamol } \\
150 \mathrm{mg} / \mathrm{kg} \text { ) }\end{array}$ & $99.16 \pm 0.13$ & $100.63 \pm 0.25$ & $99.92 \pm 0.33^{@}$ & $99.56 \pm 0.31^{\circledR}$ & $99.42 \pm 0.12^{@}$ & $99.28 \pm 0.10^{@}$ \\
\hline $\begin{array}{l}\mathrm{MERC}(200 \\
\mathrm{mg} / \mathrm{kg} 0\end{array}$ & $98.72 \pm 0.21$ & $99.86 \pm 0.05$ & $99.67 \pm 0.18^{\#}$ & $99.46 \pm 0.03^{\circledR}$ & $99.23 \pm 0.09^{\#}$ & $99.15 \pm 0.07^{*}$ \\
\hline $\begin{array}{l}\mathrm{MERC}(400 \\
\mathrm{mg} / \mathrm{k} 96 \mathrm{~g})\end{array}$ & $98.93 \pm 0.12$ & $100.16 \pm 0.04$ & $100.03 \pm 0.10^{@}$ & $99.72 \pm 0.11^{@}$ & $99.32 \pm 0.12^{@}$ & $99.03 \pm 0.18^{@}$ \\
\hline
\end{tabular}

The values are represented as mean \pm SEM or as a percentage $(n=5)$. ANOVA was used to interpret the results, followed by Dunnett's test. $\mathrm{p}<0.05, \#, \mathrm{p}<0.01$, and ${ }^{\circledR}, \mathrm{p}<0.001$ compared with control.

\section{Antipyretic test}

Statistical analyses showed that the MERC exhibited substantial antipyretic behaviour. At 2, 3, and 4 hrs, MERC reported significant implications utilizing $400 \mathrm{mg} / \mathrm{kg}$ dosage. The inhibition was based upon the dosage. Table 2 and Fig. 4 presents the influence of the extract on the rectal temperature in rats.
In-vivo Hepatoprotective activity

The hepatoprotective effects of MERC in paracetamol-intoxicated rats on serum biochemical parameters are presented in Table 3. Compared to control subjects, rats treated with Paracetamol (group II) had a substantial rise in serum SGPT, SGOT, ALP, and overall bilirubin amounts (group I). Pretreatment with MERC at 200 and $400 \mathrm{mg} / \mathrm{kg}$ for seven days (groups III and IV) displayed remarkable hepatoprotection relative to the positive control 
group (group II) in terms of serum ALP, SGPT, SGOT, and bilirubin levels, with the maximum doses administered achieving a significant reduction similar to that of the standard medication Silymarin (group II). The histopathological examination of rat livers of various groups is shown in Fig. 5.

\section{Effect of MERC on MDA and SOD levels}

LPO was raised in group II, which was shown by elevated MDA amounts compared to group-I. Pretreatment with MERC at 200 and $400 \mathrm{mg} / \mathrm{kg}$ substantially lowered the level of MDA, which was almost equal to that of rats receiving the silymarin drug, respectively. The amounts of the anti-oxidant enzyme SOD were substantially improved in the groups treated with MERC. The extract has shown optimum hepatoprotection at a $400 \mathrm{mg} / \mathrm{kg}$ dosage, as seen in Table 4 and Fig. 6.

\section{Drug likeliness}

In order to analyze the physicochemical properties of selected 12 active compounds, DruLito software was used. Except for five compounds, all the remaining compounds complied with the Lipinski law. (Table 4, respectively). The fundamental physicochemical properties of TPSA and AMR primarily provide the roles of medication ingestion, delivery, and penetration.

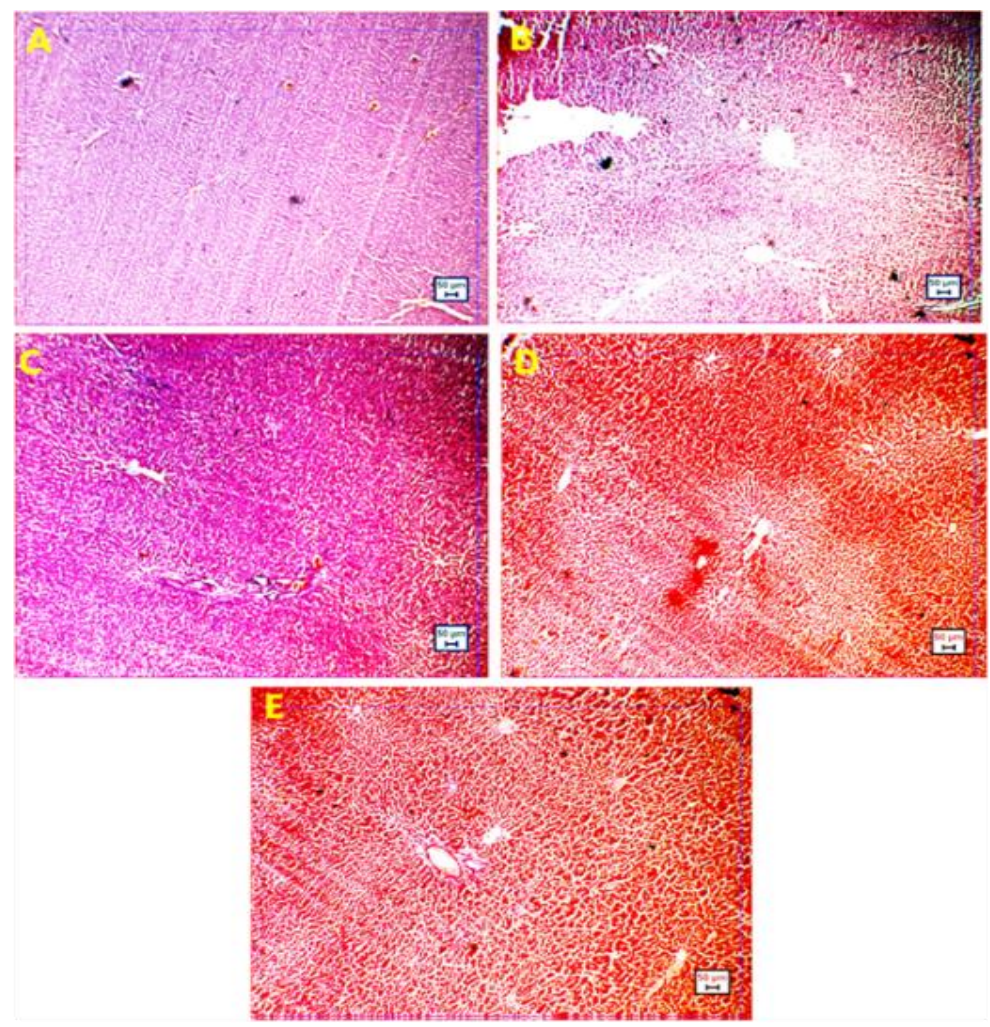

Fig. 5 : Histopathology of the liver of rats from different groups. A: Liver of normal rat showing normal hepatic architecture. B: Liver of rat administered paracetamol showing severe degeneration, nuclear pyknosis, necrotic cells, congestion, and infiltration throughout the liver, C: Silymarintreated rat liver showing normal hepatocytes with mild infiltration and very mild congestion in portal areas. D: MERC $(200 \mathrm{mg} / \mathrm{kg})$ treated rat liver showing mild regions in congestion with normal hepatocytes and intact hepatic cords. E: MERC $(400 \mathrm{mg} / \mathrm{kg})$ treated rat liver leading to mild infiltration and congestion without any degeneration. 


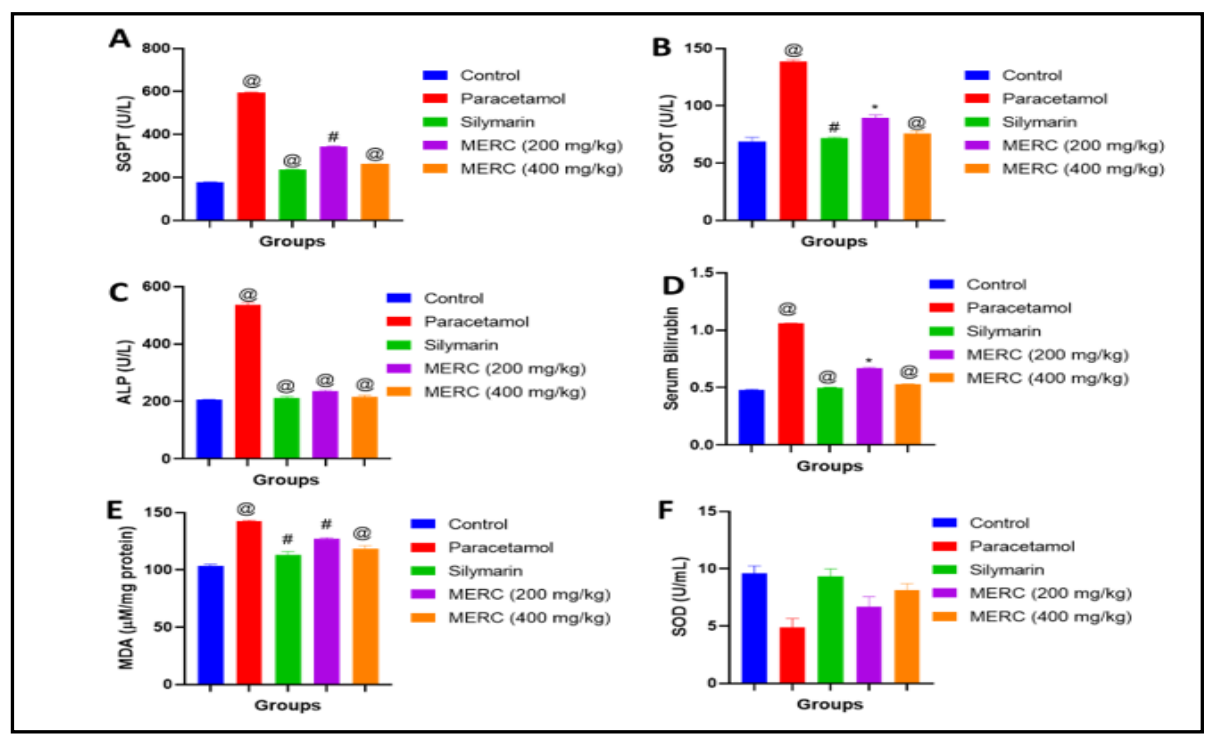

Fig. 6: Graph represents the effect of Methanol extract of R. cana on level of SGPT (B) enzymes level in Paracetamol-treated Wistar rats (A)Represent the levels of SGPT (B) Represent the levels of SGOT (C) Represent the levels of ALP (D) Represent the levels of Serum Bilirubin (E) Represent the levels of MDA (F) Represent the levels of SOD. Values are expressed as Mean \pm $\mathrm{SE}$ at level of significance, ${ }^{*}, \mathrm{p}<0.05,{ }^{\#}, \mathrm{p}<0.01$ and ${ }^{\circledR}, \mathrm{p}<0.001$ in comparison with normal control

\section{Molecular Docking Studies}

Using the PyRx program, we used molecular docking to assess the binding interactions of phytochemical constituents of $R$. cana extract with TGF- (PDB: IVJY) and PPAR (PDB ID: 5HYK). Both selected targets were concerned with positive hepatotoxicity.
To assess the comparative binding interactions of selected phytochemical constituents and the standard, Silymarin with both targets. From the results, binding affinity was significant for Vitexin, Orientin and Luteolin-3',4'-dimethyl ether for both the targets (Table 5-7 \& Fig. $7 \& 8)$.

Table 3: Effects of MERC on serum biochemical parameters in Paracetamol-intoxicated rats

\begin{tabular}{|c|c|c|c|c|c|c|}
\hline Group & SGPT (U/L) & SGOT (U/L) & $\mathbf{A L P}(\mathbf{U} / \mathbf{L})$ & $\begin{array}{c}\text { Serum } \\
\text { Bilirubin }\end{array}$ & MDA & SOD \\
\hline Control & $178.22 \pm 1.23$ & $68.85 \pm 3.63$ & $205.31 \pm 1.98$ & $0.48 \pm 0.005$ & $103.45 \pm 1.36$ & $9.58 \pm 0.66$ \\
\hline Paracetamol & $594.23 \pm 2.75^{\circledR}$ & $138.52 \pm 1.85^{\circledR}$ & $536.46 \pm 7.85^{\circledR}$ & $1.06 \pm 0.002^{@}$ & $142.55 \pm 0.78^{\circledR}$ & $4.86 \pm 0.78^{@}$ \\
\hline $\begin{array}{c}\text { Silymarin } \\
(100 \mathrm{mg} / \mathrm{kg})\end{array}$ & $235.12 \pm 3.52^{\circledR}$ & $71.86 \pm 0.68^{\#}$ & $211.67 \pm 5.15^{@}$ & $0.5 \pm 0.003^{\circledR}$ & $112.8 \pm 3.22^{\#}$ & $9.33 \pm 0.65^{@}$ \\
\hline $\begin{array}{c}\text { MERC (200 } \\
\mathrm{mg} / \mathrm{kg})\end{array}$ & $343.56 \pm 3.65^{\#}$ & $89.23 \pm 2.65^{*}$ & $236.87 \pm 2.45^{@}$ & $0.67 \pm 0.008^{*}$ & $126.85 \pm 1.22^{\#}$ & $6.67 \pm 0.89^{*}$ \\
\hline $\begin{array}{c}\text { MERC (400 } \\
\mathrm{mg} / \mathrm{kg})\end{array}$ & $261.45 \pm 1.35^{\circledR}$ & $75.66 \pm 2.31^{@}$ & $216.8 \pm 4.58^{@}$ & $0.53 \pm 0.002^{\circledR}$ & $118.69 \pm 2.51^{@}$ & $8.15 \pm 0.55^{@}$ \\
\hline
\end{tabular}

Values are expressed as mean \pm SEM or percentage $(n=5)$. The data were analyzed by one-way ANOVA followed by Dunnett's test. "p< $0.05,{ }^{\#}, \mathrm{p}<.01$ and ${ }^{\circledR}, \mathrm{p}<0.001$ compared with control. 
Table 4: Physicochemical properties of active compounds and accordance with the rule of Druglikeliness

\begin{tabular}{|c|c|c|c|c|c|c|c|c|c|}
\hline Ligand & MW & Logp & Alogp & HBA & HBD & TPSA & AMR & nRB & $\begin{array}{c}\text { No. of } \\
\text { Violations }\end{array}$ \\
\hline Orientin & 427.9 & -0.36 & -3.22 & 11 & 0 & 35.53 & 114.1 & 3 & 1 \\
\hline $\begin{array}{c}\text { Luteolin 3',4'- } \\
\text { dimethyl } \\
\text { ether }\end{array}$ & 467.9 & 0.55 & -2.65 & 12 & 0 & 80.29 & 124.4 & 6 & 1 \\
\hline $\begin{array}{c}\text { Genistein } \\
\text { alpha- } \\
\text { Terpineol }\end{array}$ & 260 & 1.043 & -0.39 & 5 & 0 & 26.3 & 78.92 & 1 & 0 \\
\hline Vitexin & 412 & -0.71 & -2.66 & 10 & 0 & 35.53 & 112.5 & 3 & 0 \\
\hline Isoorientin & 427.9 & -0.36 & -3.22 & 11 & 0 & 35.53 & 114.1 & 3 & 1 \\
\hline Rhynchosin & 292 & 2.263 & -1.24 & 7 & 0 & 26.3 & 83.44 & 1 & 0 \\
\hline Isovitexin & 412 & -0.71 & -2.66 & 10 & 0 & 35.53 & 112.5 & 3 & 1 \\
\hline Cubenol & 196 & 4.054 & 1.364 & 1 & 0 & 0 & 66.87 & 1 & 0 \\
\hline Vicenin-2 & 563.9 & -2.55 & -5.09 & 15 & 0 & 44.76 & 144.9 & 5 & 2 \\
\hline Gallocatechin & 292 & 1.2 & -1.5 & 7 & 0 & 9.23 & 82.67 & 1 & 0 \\
\hline Silymarin & 482.12 & 0.855 & -1.848 & 10 & 5 & 155.14 & 132.21 & 4 & 1 \\
\hline
\end{tabular}

Table 5: Molecular Docking of Selected Compounds from $R$. cana with various targets associated with hepatotoxicity.

\begin{tabular}{||c|c|c||}
\hline \multirow{2}{*}{ Ligands } & \multicolumn{2}{|c||}{ Binding affinities (Kcal/mol) } \\
\cline { 2 - 3 } Gallocatechin & 1VJY & 5HYK \\
\hline Rhynchosin & -8.1 & -8.4 \\
\hline Genistein & -9.7 & -8.5 \\
\hline$\alpha-$ Terpineol & -9.4 & -8.1 \\
\hline Cubenol & -6.3 & -6.4 \\
\hline Vitexin & -7.3 & -7.4 \\
\hline Orientin & -10.3 & -8.8 \\
\hline Isovitexin & -10 & -8.7 \\
\hline Isoorientin & -9.1 & -7.4 \\
\hline Vicenin-2 & -9.9 & -7.4 \\
\hline $\begin{array}{c}\text { Luteolin-3',4'- } \\
\text { dimethylether }\end{array}$ & -8 & -1.9 \\
\hline Silymarin & -10.1 & -8.5 \\
\hline \hline
\end{tabular}


Table 6: Interactions with ligands of $R$. cana with transforming growth factor- $\beta$ (PDB: IVJY)

\begin{tabular}{|c|c|c|c|c|}
\hline \multirow{2}{*}{ Ligands } & \multirow{2}{*}{$\begin{array}{c}\text { Binding } \\
\text { Affinity, } \\
\Delta \mathrm{G} \\
\text { (Kcal/mol) }\end{array}$} & \multicolumn{3}{|c|}{ Amino acids involved and Distance $\left(\mathrm{A}^{\circ}\right)$} \\
\hline & & $\begin{array}{l}\text { Hydrogen Binding } \\
\text { Interactions }\end{array}$ & Hydrophobic Interactions & $\begin{array}{l}\text { Electrostatic } \\
\text { Interactions }\end{array}$ \\
\hline Vitexin & -10.3 & $\begin{array}{l}\text { ASP A:351 (5.15), } \\
\text { LYS A:337 (6.42) }\end{array}$ & $\begin{array}{c}\text { ALA A:350 (5.77), LEU } \\
\text { A:260 (5.73), VAL A:219 } \\
\text { (4.81, 5.26), ALA :A230 } \\
\text { (5.48), LEU A:340 (5.19, } \\
\text { 6.12), GLY A:286 (4.00), } \\
\text { ILE A:211 (5.57), GLY } \\
\text { A:212 (3.32) }\end{array}$ & $\begin{array}{c}\text { LYS A:232 } \\
\quad(5.00)\end{array}$ \\
\hline $\begin{array}{l}\text { Luteolin-3',4'- } \\
\text { dimethylether }\end{array}$ & -10.1 & $\begin{array}{l}\text { LYS A:232 (5.12), } \\
\text { ASP A:351 (3.73), } \\
\text { SER A:280 (4.32), } \\
\text { LEU A:278 (5.01) }\end{array}$ & $\begin{array}{c}\text { PHE A:289 (5.20), LYS } \\
\text { A:337 (4.28, 4.44), ALA } \\
\text { A:230 }(5.87), \text { LEU A:340 } \\
(5.29,6.05)\end{array}$ & - \\
\hline Orientin & -10 & $\begin{array}{l}\text { HIS A:283 (4.48), } \\
\text { LYS A:232 (5.04) }\end{array}$ & $\begin{array}{c}\text { LEU A:340 (5.17), ALA } \\
\text { A:230 (6.09), VAL A:219 } \\
\text { (5.26), ALA A:350 (6.02), } \\
\text { LEU A:260 (6.55), ILE } \\
\text { A:211 }(4.97,6.29)\end{array}$ & - \\
\hline Silymarin & -10.6 & $\begin{array}{l}\text { ASP A:351 (3.84), } \\
\text { TYR A:249 (6.43), } \\
\text { LYS A:337 (4.41), } \\
\text { LEU A:278 (4.48), } \\
\text { ASP A:290 (4.18) }\end{array}$ & $\begin{array}{c}\text { ALA A:350 (6.43), LYS } \\
\text { A:232 (4.13), ALA A:230 } \\
\text { (5.31), LEU A:260 (6.22), } \\
\text { LEU A:340 (6.36), VAL } \\
\text { A:219 }(6.36), \text { LYS A:337 } \\
(4.93,5.60)\end{array}$ & - \\
\hline
\end{tabular}

Table 7: Interactions of with ligands of $R$. cana with peroxisome proliferator-activated receptor $\alpha$ (PPAR $\alpha$ ) (PDB ID: 5HYK)

\begin{tabular}{|c|c|c|c|c|}
\hline \multirow{2}{*}{ Ligands } & \multirow{2}{*}{$\begin{array}{c}\text { Binding } \\
\text { Affinity, } \Delta G \\
(\text { Kcal } / \mathbf{m o l})\end{array}$} & \multicolumn{3}{|c|}{ Amino acids involved and Distance $\left(\mathrm{A}^{\circ}\right)$} \\
\hline & & $\begin{array}{l}\text { Hydrogen Binding } \\
\text { Interactions }\end{array}$ & Hydrophobic Interactions & $\begin{array}{l}\text { Electrostatic } \\
\text { Interactions }\end{array}$ \\
\hline Vitexin & -8.8 & $\begin{array}{l}\text { THR A:283 (4.65), } \\
\text { ASN A:219 (4.05, } \\
\text { 4.39), MET A:220 } \\
(4.85)\end{array}$ & $\begin{array}{c}\text { LEU A:321 (5.42), GLU } \\
\text { A:286 (7.34), MET A:220 } \\
\text { (4.75), ASN A:221 (3.99), } \\
\text { SER A:323 (4.99), MET } \\
\text { A:320 (3.23, 4.90), }\end{array}$ & - \\
\hline Orientin & -8.7 & $\begin{array}{l}\text { MET A:220 (4.28), } \\
\text { ASN A:219 (3.21), } \\
\text { TYR A:334 (3.53) }\end{array}$ & LEU A:321 (4.63), & $\begin{array}{l}\text { GLU A:286 } \\
(7.04), \text { MET } \\
\text { A:320 (5.06) }\end{array}$ \\
\hline $\begin{array}{l}\text { Luteolin-3',4'- } \\
\text { dimethylether }\end{array}$ & -8.5 & LEU A:331 (5.45) & $\begin{array}{c}\text { MET A:330 (6.96), LEU } \\
\text { A:321 (5.26, 5.59), PHE } \\
\text { A:273 (4.65), TYR A:314 } \\
(5.75), \text { HIS A:440 (5.16), } \\
\text { VAL A:324 (6.38) }\end{array}$ & $\begin{array}{c}\text { CYS A:276 (4.46, } \\
4.49)\end{array}$ \\
\hline Silymarin & -8.2 & $\begin{array}{l}\text { GLU A:286 (5.76), } \\
\text { CYS A:276 (4.30), } \\
\text { HIS A:440 (5.38), } \\
\text { TYR A:464 (6.99) }\end{array}$ & $\begin{array}{l}\text { MET A:220 (5.13), LEU } \\
\text { A:321 (5.37), MET A:355 } \\
(4.72), \text { CYS A:276 (4.51) }\end{array}$ & $\begin{array}{c}\text { MET A:320 } \\
(5.84)\end{array}$ \\
\hline
\end{tabular}

\section{ADMET Analysis}

Ligands have been checked for ADMET attributes using admetSAR. In the research study, ADMET properties for compounds are measured using admetSAR. All the compounds displayed negative for AMES toxicity. The $\mathrm{HIA}, \mathrm{BBB}$, and $\mathrm{LD}_{50}$ tests for the compounds are mentioned in Table 8. 


\section{Discussion}

To objectively explain its folkloric applications, the tests were intended to investigate $R$. cana's pharmacological activity. The existence of alkaloids, flavonoids, tannins, steroids, volatile oils, saponins, fixed oils, proteins, and amino acids has been demonstrated through phytochemical analyses of MERC.

Fever is an abrupt process reaction caused by immune system stimulation. According to previous studies, fever is caused by subcutaneous administration of Brewer's yeast, allowing the body to release fever-inducing prostaglandins. The yeast-induced pyrexia process of the Brewer is an optimal way to evaluate synthetic and natural products' effects $^{37 \& 38}$. It is necessary to obtain an antipyretic by impeding the development of prostaglandins, which is likely to be achieved by blocking the enzyme COX-2Several facilitators, such as TNF, IL-1, IL-6, and interferons, contribute to temperature elevation and can be culpable for the antipyretic findings obtained in countering their activity ${ }^{39 \& 40}$. By inhibiting PGE2 in the hypothalamus, most antipyretic agents suppress fever via the central pathway. Still, stimulated leucocytes and endothelial cells in the peripheral areas can also be a possible drug target. MERC administration culminated in a drop in rectal temperature. This temperature decline may be attributed to $R$. cana of pharmacologically active constituents that interfere with prostaglandin synthesis. While complex biochemical processes exist during prostaglandin biosynthesis, further study is required to establish the precise location in this complex process in which the extract confers its antipyretic repercussions.

For its function in drug metabolization and detoxification, the liver is a site for toxicity. By attaching covalently to sulfhydryl groups in the liver, Paracetamol overdose may induce liver toxicity, thereby causing lipid peroxidation and cell necrosis ${ }^{41}$. An unusual rise in serum enzymes SGOT, SGPT, ALP indicates hepatic disruption and leakage into the blood ${ }^{42}$. On the other side, bilirubin is generated inside the reticuloendothelial system by the enzymatic cleavage of heme. To determine the liver's working, it is a significant parameter and a marker ${ }^{43 \& 44}$. It has been shown that plant-based secondary metabolites control various health conditions, including liver disorders. It has been argued that flavonoids and phenolic compounds are potentially hepatoprotective agents among different secondary metabolites due to their free-radical scavenging properties $^{45 \&} 46$.

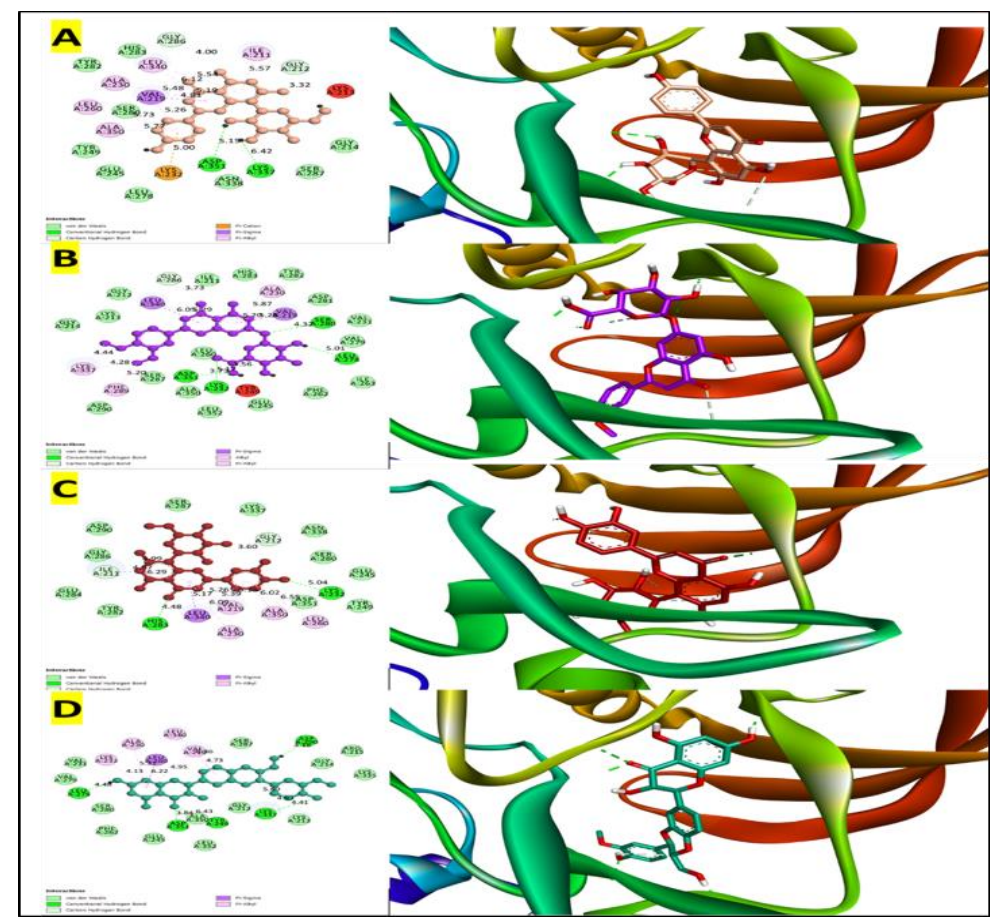

Fig. 7: 2D and 3D interaction poses of various ligands (a) Vitexin, (b) Orientin (c) Luteolin-3',4'-dimethylether, (d) Silymarin, with transforming growth factor- $\beta$ (PDB: IVJY) in molecular docking. 
For its function in drug metabolization and detoxification, the liver is a site for toxicity. By attaching covalently to sulfhydryl groups in the liver, Paracetamol overdose may induce liver toxicity, thereby causing lipid peroxidation and cell necrosis ${ }^{41}$. An unusual rise in serum enzymes SGOT, SGPT, ALP indicates hepatic disruption and leakage into the blood ${ }^{42}$. On the other side, bilirubin is generated inside the reticuloendothelial system by the enzymatic cleavage of heme. To determine the liver's working, it is a significant parameter and a marker ${ }^{43 \& 44}$. It has been shown that plant-based secondary metabolites control various health conditions, including liver disorders. It has been argued that flavonoids and phenolic compounds are potentially hepatoprotective agents among different secondary metabolites due to their free-radical scavenging properties $45 \& 46$.

Paracetamol (toxic control) treatment has resulted in serum elevation of SGOT, SGPT, ALP, and bilirubin. MERC significantly decreases the serum amounts of SGPT, SGOT, ALP, and bilirubin in a dose-dependent pattern relative to the normal medication silymarin from the current analysis findings. It reduces the amount of intracellular biomarker enzyme leakage by stabilizing the hepatic cell membrane. The substantial reduction in MDA levels with a rise in MERC dosage implies that a drop in lipid peroxidation could be the primary mechanism for hepatoprotection. Furthermore, the increase in SOD levels often means that MERC is helping to repair antioxidant protection mechanisms. The biochemical study also showed that Silymarin had a more significant hepatoprotective function than MERC ${ }^{47}$. Biochemical findings were confirmed by histopathological examination of rat livers since normal livers were shown in the control group (Fig. 5A).

In contrast, severe degeneration, liver congestion, penetration, and nuclear pycnosis were found in rats in which Paracetamol was administered (Fig. 5B). The rats treated with Silymarin exhibited almost normal biochemical effects with normal liver histology. However, in the livers of MERC-treated rats from groups IV and $\mathrm{V}$, only slight congestion, infiltration, and even mild degeneration have been reported. . (Fig. 5 D \& E)

Considering Lipinski's five rule, most of the compounds violated these, as they were natural products ${ }^{48}$. Among the screened phytoconstituents of $R$. cana, Genistein, alphaTerpineol, Vitexin, Rhynchosin, and Cubenol Gallocatechin, the rest of the phytoconstituents follows Lipinski's rule of five.

Tests against TGF- $\beta$ and PPAR a, with phytoconstituents derived from $R$. cana, were performed in In-silico. It showed that Vitexin, Orientin, Luteolin-3',4'-dimethyl ether had a consistently significant linkage with proteins. TGF- $\beta$ plays a vital part in chronic liver disorders and controls all phases of liver disease $^{49}$. The protein TGF- $\beta$ was inhibited by the three compounds, and their interaction with TGF- $\beta$ was greater than that of Silymarin. Therefore, properly targeting this protein in specific cells facilitates a therapeutic impact on liver disorders. $\mathrm{PPAR}_{\alpha}$ in the liver protein tends to cope with different metabolic problems ${ }^{50}$. An advantage in the management of metabolic diseases is the stimulation of PPAR $_{\alpha}$. These three compounds, compared to Silymarin, proved their efficacy through association with PPAR $\alpha$.

There are more opportunities for successful phytoconstituents from herbs in this postgenomic age, whereas conventional medicine helps find new drugs for dreadful diseases. The performance rate for the production of new synthetic medicines is one out of ten thousand, while it may be as big as one-fourth or even more for the new medicinal phytoconstituent from commonly used plants ${ }^{51}$. In this sense, by utilizing In vivo and In silico methods to carry out a more reliable hepatoprotection, we have justified the conventional use of $R$. cana.

\section{Conclusion}

MERC has been studied for in vivo antipyretic and hepatoprotective activities, whereas In silico has been examined for some identified phytoconstituents. Our study has shown that MERC has had considerable antipyretic and hepatoprotective effects in Wistar rats against Paracetamol-induced toxicity. Besides, it is possible that some of the screened compounds could be responsible for the reported hepatoprotective action from the In silico studies. Therefore, $R$. cana is an intriguing paradox that can show hepatoprotective properties and needs more analysis. 
Table 8: ADME / T Properties of R. cana compounds

\begin{tabular}{|c|c|c|c|c|c|c|c|c|c|c|c|c|c|c|c|c|c|c|c|}
\hline \multirow[b]{2}{*}{ SNo } & \multirow[b]{2}{*}{ Lizal } & \multicolumn{5}{|c|}{ itbengtion } & \multirow{2}{*}{ 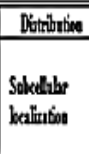 } & \multicolumn{8}{|c|}{ Inenblian } & \multicolumn{4}{|c|}{ Tondity } \\
\hline & & $B B B$ & HII & Com: & 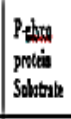 & \begin{tabular}{|l} 
RaulOrpaix \\
Croin \\
Imprpoute \\
\end{tabular} & & $\begin{array}{l}\text { CPRS:DS } \\
\text { Solbtant }\end{array}$ & 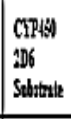 & 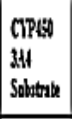 & 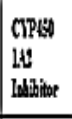 & 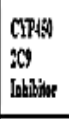 & 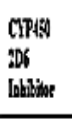 & 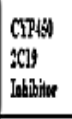 & 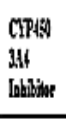 & $\begin{array}{l}\text { Alis } \\
\text { Irvicity }\end{array}$ & Grian & 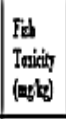 & 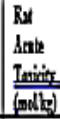 \\
\hline 1 & Vilexin & 0.6472 & 0.9442 & 0.9163 & 0.5863 & 0.9214 & 0.5728 & 0.8041 & 0.8767 & 0.6032 & 0.8355 & 0.9071 & 0.9476 & 09240 & 0.8310 & 0.7232 & 0.9553 & 0.9771 & 23604 \\
\hline 2 & $\begin{array}{l}\text { Luteolin-3,4- } \\
\text { dimethylether }\end{array}$ & 0.9068 & 0.6737 & 0.6036 & 0.6546 & 0.4436 & 0.662 & 0.8072 & 0.9161 & 0.5871 & 0.8108 & 0.8538 & 0.9307 & 0.8909 & 0.7521 & 0.8536 & 0.4469 & 0.7843 & 27471 \\
\hline 3 & Oreetin & 0.6472 & 0.442 & 0.9163 & 0.5863 & 0.9214 & 0.5728 & 0.8041 & 0.8767 & 0.6032 & 0.8355 & 0.9071 & 0.9476 & 0.9240 & 0.8310 & 0.7232 & 0.9553 & 0.9771 & 23664 \\
\hline 4 & Siljmarin & 0.7675 & 0.5998 & 0.5908 & 0.6141 & 0.8552 & 0.6746 & 0.7612 & 0.8735 & 0.5502 & 0.7709 & 0.6354 & 0.9231 & 0.5992 & 0.5057 & 0.9133 & 0.9385 & 0.6999 & 22206 \\
\hline
\end{tabular}

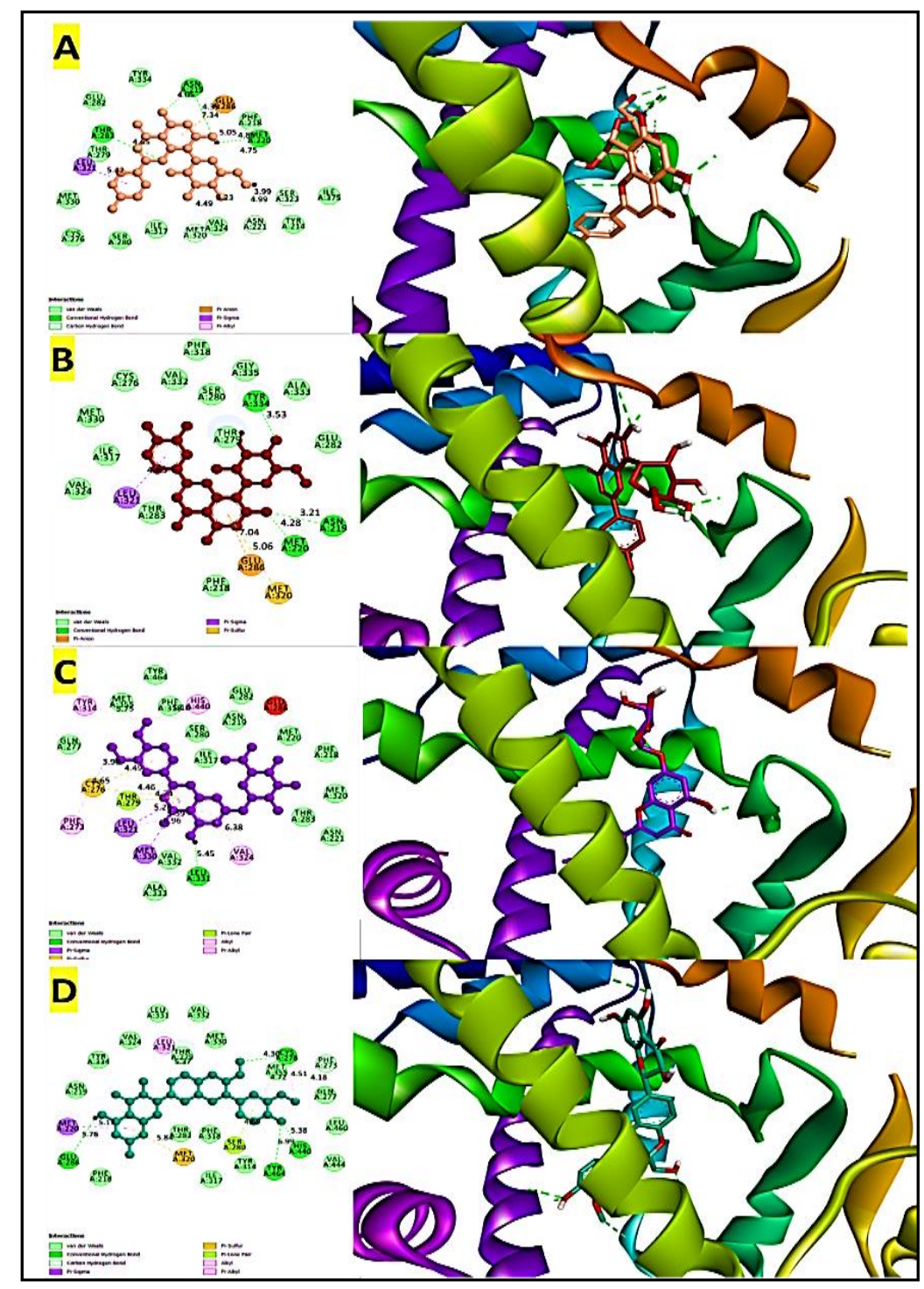

Fig. 8: 2D and 3D interaction poses of various ligands (a) Vitexin, (b) Orientin (c) Luteolin-3',4'dimethylether, (d) Silymarin with peroxisome proliferator-activated receptor $\alpha$ (PPAR $\alpha)$ (PDB ID: 5HYK) in molecular docking. 


\section{Acknowledgement}

The authors thank the management of the University College of Pharmaceutical Sciences, Andhra University, Visakhapatnam, for providing the facilities to perform the work

\section{REFERENCES}

1. C. A. Rice-Evans, N. J. Miller, P. G. Bolwell, P. M. Bramley, J. B. Pridham, "The relative anti-oxidant activities of plant-derived polyphenolic flavonoids", Free Radic Res, 22, 375-383 (1995).

2. K. G. Singhal, G. D. Gupta, "Hepatoprotective and anti-oxidant activity of methanolic extract of flowers of Nerium oleander against CCl4-induced liver injury in rats", Asian Pac J Trop Med, 5, 677-685, (2012).

3. B. Romano, G. Lucariello, and R. Capasso. "Topical Collection Pharmacology of Medicinal Plants", Multidisciplinary Digital Publishing Institute, 2021.

4. T. Nilima, S. Pranali and T. Madhura "Medicinal plant as a source of Antipyretic drug: A Review", Asian J Pharm Technol, 11, 84-87, (2021).

5. T. Pullaiah and M. Ramaiah. Handbook of Research on Herbal Liver Protection: Hepatoprotective Plants: CRC Press, 2021.

6. A. Khan, M. Rahman and S. Islam, "Antipyretic activity of Peperomia pellucida leaves in rabbit", Turk J Biol, 32, 37-41, (2008).

7. T. B. Emran, S. Ahmed, S. Zahan, A. Rakib, M. S. Hasan, M. N. Amin, et al., "Sedative, anxiolytic, antinociceptive, antiinflammatory and antipyretic effects of a chloroform extract from the leaves of Urena sinuata in rodents", J Appl Life Sci Int, 16(3), 1-19, (2018).

8. C. Luo, M. L. He and L. Bohlin, "Is COX2 a perpetrator or a protector? Selective COX-2 inhibitors remain controversial", Acta Pharmacol Sin, 26, 926-933, (2005).

9. S. K. Asrani, H. Devarbhavi, J. Eaton and P. S. Kamath, "Burden of liver diseases in the world", J Hepatol, 70, 151-171, (2019)

10. J. T. Dipiro, R. L. Talbert, G. C. Yee, G. R. Matzke, B. G. Wells, L. M. Posey. Pharmacotherapy: A Pathophysiologic Approach, ed: McGraw-Hill Medical, New York, 2014.

11. K. Du, A. Ramachandran and $\mathrm{H}$. Jaeschke, "Oxidative stress during acetaminophen hepatotoxicity: Sources, pathophysiological role and therapeutic potential", Redox Biol, 10, 148-156, (2016).

12. J. A. Hinson, D. W. Roberts, L. P. James, "Mechanisms of acetaminophen-induced liver necrosis", Handb Exp Pharmacol, 196, 369-405, (2010).

13. M. Saleem, H. Iftikhar, "A Rare Case of Acetaminophen Toxicity Leading to Severe Kidney Injury", Cureus, 11(6), e5003, (2019).

14. U. Quattrocchi. "CRC world dictionary of medicinal and poisonous plants: common names, scientific names, eponyms, synonyms, and etymology (5 Volume Set): CRC press; 2012.15(2) 1-12. 2002, Journal of agricultural and food chemistry 58(14): 8259-8264. 2010

15. D. Adinarayana and P. Ramachandraiah, "C-Glycosides of Rhynchosia cana", J Nat Prod, 49, 1158-1159, (1986).

16. R. Vimala, S. Nagarajan, M. Alam, T. Susan andS. Joy, "Anti-inflammatory and antipyretic activity of Michelia champaca Linn., (white variety), Ixora brachiata Roxb. and Rhynchosia cana (Willd.) D.C. flower extract", Indian J Exp Biol, 35, 1310-1314, (1997).

17. A. Rammohan, G. M. Reddy, B. V. Bhaskar, D. Gunasekar and G. V. Zyryanov, "Phytochemistry and pharmacological activities of the genus Rhynchosia: a comprehensive review", Planta, 251(1), 1-15 (2019).

18. W. H. Organization. Geneva; Quality Control Method for Medicinal Plant Materials. AITBS Publisher and Distributors., New Delhi; 2002.

19. C. Kokate, "Practical Pharmacognosy. $3^{\wedge}<$ rd> ed", New Delhi VPBN, 3, 107$111,(1991)$

20. G. E. Trease, "Textbook of pharmacognosy", (1957).

21. A. Zaoui, Y . Cherrah, N. Mahassini, K. Alaoui, H. Amarouch and M. Hassar, "Acute and chronic toxicity of Nigella sativa fixed oil", Phytomedicine, 9, 69-74, (2002)

22. B. Jain, B. Rathi, P. Thakurdesai and S. Bodhankar, "Antipyretic activity of aqueous extract of leaves of Cocculus hirsutus", Indian J Nat Prod, 23, 26-29, (2007).

23. P. K. SMITH and W. Hambourger, "The ratio of the toxicity of acetanilid to its antipyretic activity in rats", J Pharmacol Exp Ther, 54, 346-351, (1935).

24. S. Hajare, S. Chandra, S. Tandan, J. Sarma, J. Lal and A. Telang, "Analgesic and antipyretic activities of Dalbergia 
sissoo leaves", Indian J Pharmacol, 32, 357-360, (2000).

25. Z. Al Mahmud, T. B. Emran, N. Qais, S. C. Bachar, M. Sarker and M. M. Uddin, "Evaluation of analgesic, antiinflammatory, thrombolytic and hepatoprotective activities of roots of Premna esculenta (Roxb)", J Basic Clin Physiol Pharmacol, 27, 63-70, (2016).

26. M. R. H. Bulbul, M. A. Rahman, M. Z. Rahman, T. B. Emran, M. Afroze, M. Khan, et al., "Leea macrophylla (Roxb.) root extract reverses $\mathrm{CCl} 4$ induced liver injury through upregulation of antioxidative gene expression: a molecular interaction for therapeutic inception", $\boldsymbol{A d} \boldsymbol{d}$ Tradit Med, 20, 35-52, (2020).

27. B. K. Chandan, A. K. Saxena, S. Shukla, N. Sharma, D. K. Gupta, K. Singh, et al., "Hepatoprotective activity of Woodfordia fruticosa Kurz flowers against carbon tetrachloride induced hepatotoxicity", $\boldsymbol{J}$ Ethnopharmacol, 119, 218-224, (2008).

28. U. Rashid, M. R . Khan and M. Sajid, "Hepatoprotective potential of Fagonia olivieri DC. against acetaminophen induced toxicity in rat", BMC Complement Altern Med, 16(1), 449, (2016).

29. R. Smyth, J. A. Turton, C. J. Clarke, M. J. York, T. O. Dare, C. S. Lane, et al., "Identification of superoxide dismutase as a potential urinary marker of carbon tetrachloride-induced hepatic toxicity", Food Chem Toxicol, 46, 2972-2983, (2008).

30. Y. Wu, L. Li, T. Wen and Y. Q. Li, "Protective effects of echinacoside on carbon tetrachloride-induced hepatotoxicity in rats", Toxicology, 232, 50-56, (2007).

31. G. K. Veeramachaneni, V. Thunuguntla, M. Bhaswant, M. L. Mathai and J. S. Bondili, "Pharmacophore Directed Screening of Agonistic Natural Molecules Showing Affinity to 5HT2C Receptor", Biomolecules, 9(10), 556, (2019).

32. C. S. Bokka, G. K. Veeramachaneni, V. Thunuguntla, J. Bobbillapati and J. S. Bondili, "Peptide Mapping, In Silico and In Vivo Analysis of Allergenic Sorghum Profilin Peptides", Medicina (Kaunas), 55(5), 178, (2019).

33. V. Venkatesh, V. Krishna, C. Jayabaskaran, K. Pradeepa, S. Shastri and G. Lingaraju, "Antimicrobial studies of stem bark extract and their phytoconstituent from Semecarpus anacardium L", Int J Fundam Appl Sci, 7, 2-9, (2018).
34. S. Shastri, V. Krishna, R. Kumar, R. Venkateshand K. Pradeepa, "Phytochemical analysis, Antibacterial property and molecular docking studies of Mammea suriga kosterm", World J Pharm Pharm Sci, 4, 331-340, (2016).

35. F. Cheng, W. Li, Y. Zhou, J. Shen, Z. Wu, G . Liu, et al., " AdmetSAR: a comprehensive source and free tool for assessment of chemical ADMET properties. ACS Publications", J. Chem. Inf. Model. , 52, 11, 3099-3105 (2012).

36. H. Yang, C. Lou, L. Sun, J. Li, Y. Cai, Z. Wang, et al., "admetSAR 2.0: webservice for prediction and optimization of chemical ADMET properties", Bioinformatics, 35, 1067-1069, (2019).

37. B. P. Devi, R. Boominathan and S. C. Mandal, "Evaluation of antipyretic potential of Cleome viscosa Linn. (Capparidaceae) extract in rats", $\boldsymbol{J}$ Ethnopharmacol, 87, 11-13, (2003).

38. I. Khan, M. Nisar, F. Ebad, S. Nadeem, M. Saeed, H. Khan, et al., "Antiinflammatory activities of Sieboldogenin from Smilax china Linn.: experimental and computational studies",

Ethnopharmacol, 121, 175-177, (2009).

39. M. Rawlins and R. Postgrad, editors. Mechanism of salicylate-induced antipyresis. Pharmacology Thermoregulatory Proceeding Satellite Symposium, 1973.

40. J. Miller, "Hyperthermia and hypothermia", Textbook of Veterinary Internal Medicine, ed, 5, 6-10, (2000).

41. N. Tabassum and S. S. Agrawal, "Hepatoprotective activity of Eclipta alba Hassk. against paracetamol induced hepatocellular damage in mice", $\boldsymbol{J} \boldsymbol{k}$ Practitioner, 11, 278-280, (2004).

42. S. A. Center, "Interpretation of liver enzymes", Vet Clin North Am Small Anim Pract, 37(2), 297-333 (2007).

43. S. Sasidharan, S. Aravindran, L. Y. Latha, R. Vijenthi, D . Saravanan and S. Amutha, "In vitro anti-oxidant activity and hepatoprotective effects of Lentinula edodes against paracetamol-induced hepatotoxicity", Molecules, 15, 44784489, (2010).

44. A. Payasi, M. Chaudhary, B. M. Singh, A. Gupta and R. Sehgal, "Sub-acute toxicity studies of paracetamol infusion in albino wistar rats", Int J Pharm Sci Drug Res, 2, 142-145, (2010).

45. N. G. Shehab, E . Abu-Gharbieh, F. A. Bayoumi, "Impact of phenolic composition on hepatoprotective and antioxidant effects of four desert medicinal 
plants", BMC Complement Altern Med, 15, 401, (2015).

46. A. Ved, A. Gupta and A. K. Rawat "Antioxidant and Hepatoprotective Potential of Phenol-Rich Fraction of Juniperus communis Linn. Leaves", Pharmacogn Mag, 13, 108-113, (2017).

47. P. F. Surai, "Silymarin as a Natural Antioxidant: An Overview of the Current Evidence and Perspectives", AntioxidantsBasel, 4, 204-247, (2015).

48. A. Verma, "Lead finding from Phyllanthus debelis with hepatoprotective potentials", Asian Pac J Trop Biomed, 2, 1735-1737, (2012).
49. A. ropmann, S. Dooley, B. Dewidar, S. Hammad, T. Dediulia, J. Werle, et al., "TGF- $\beta 2$ silencing to target biliary-derived liver diseases", Gut, 69, 1677-1690, (2020).

50. E. M. Zardi, L. Navarini, G. Sambataro, P. Piccinni, F. M. Sambataro, C. Spina, et al., "Hepatic PPARs: their role in liver physiology, fibrosis and treatment", Curr Med Chem, 20, 3370-3396, (2013).

51. S. Y. Pan, S. F. Zhou, S. H. Gao, Z. L. Yu, S. F. Zhang, M. K. Tang, et al., "New Perspectives on How to Discover Drugs from Herbal Medicines: CAM's Outstanding Contribution to Modern Therapeutics", Evid Based Complement Alternat Med, 2013 1-25, (2013). 


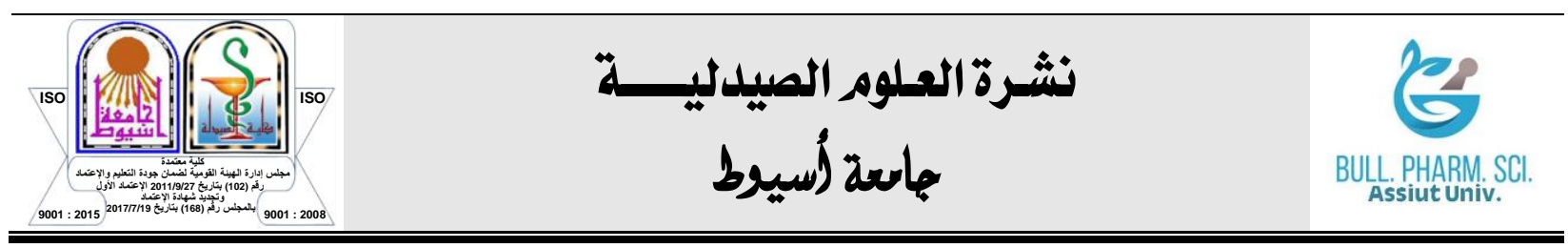

دراسات الإرساء الجزيئي و تقييم التأثير الخافض للحرارة والواقى للكبا لنبات

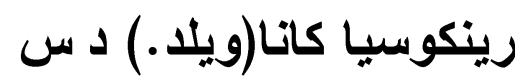

برافينا يمبادا - آريا لاكثمي ماريسيتي - جانجا راو باتو

قسم أبحاث العقاقير والكيمياء النباتية ، كلية العلوم الصيدلية ، جامعة أندرا ، فيساخاباتنام ، أندرا

$$
\text { براديش ، الهند التدات }
$$

تم تقييم التأثيرات الخافضة للحرارة و الوقاية الكبدية لمستخلص الميثانول لنبات رينكوسيا كانا

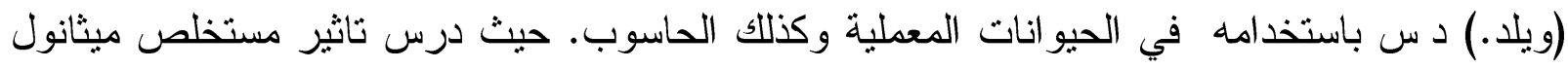

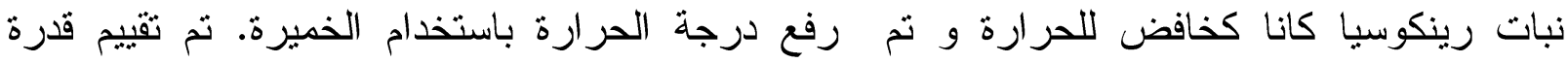

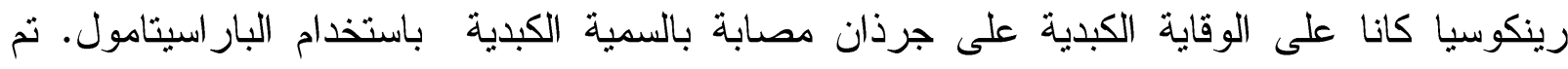

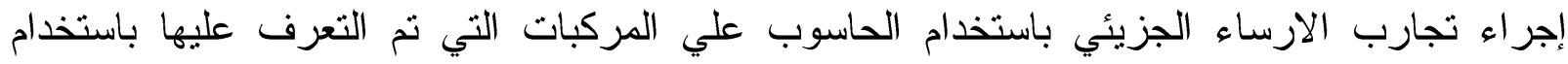

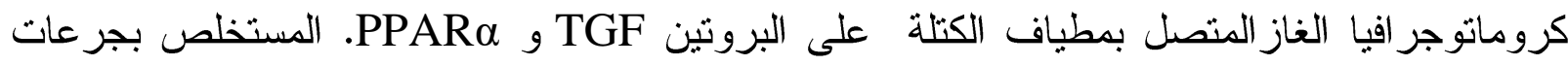

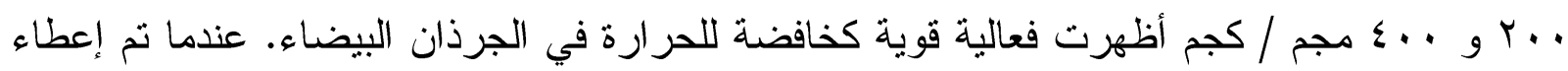

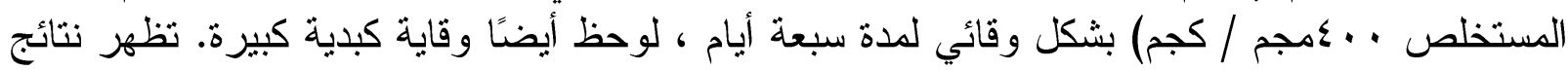

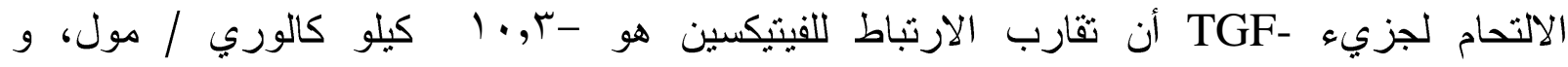

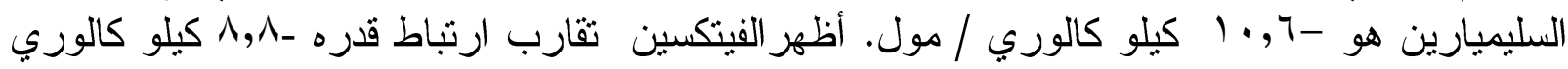

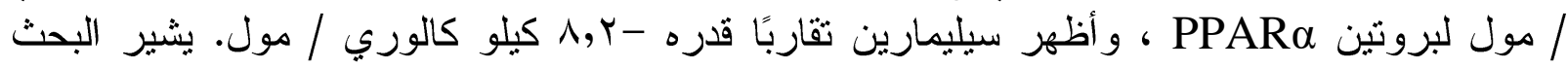

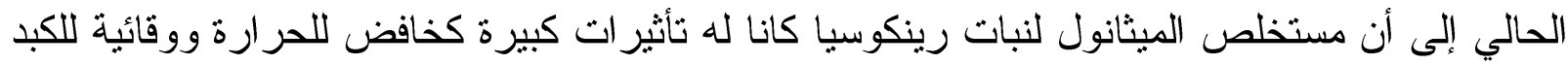

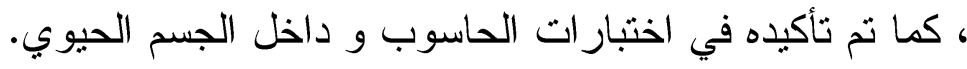

